\title{
Bronchoalveolar lavage in talc induced lung disease
}

\author{
ANDRES A REDONDO, DAVID B ETTENSOHN, MOHAMMAD KHAN, \\ NOUBAR KESSIMIAN
}

\author{
From the Department of Medicine, Division of Pulmonary Medicine, and Department of Pathology, Memorial \\ Hospital of Rhode Island, Pawtucket and Brown University, Providence, Rhode Island, USA
}

\begin{abstract}
A 65 year old woman with a history of occupational talc inhalation presented with hypoxaemia, cough, and dyspnoea with a normal chest radiograph. Bronchoalveolar lavage showed considerable lymphocytosis, with a predominance of $\mathrm{T}^{+}{ }^{+}$ $T$ lymphocytes, and open lung biopsy showed peribronchiolar granulomas containing talc crystals. Corticosteroid treatment resulted in dramatic improvement. Bronchoalveolar lavage may aid in the diagnosis of talc related lung injury.
\end{abstract}

The clinical manifestations of pulmonary talcosis range from mild, nearly asymptomatic disease to extensive, severely disabling pulmonary fibrosis.' The pathogenetic mechanism or mechanisms producing pulmonary talc toxicity have been obscured as exposure to talc is frequently accompanied by exposure to contaminants such as silica and asbestos, which are also known to cause pulmonary disease. We report the results of bronchoalveolar lavage in a patient with chronic inhalational exposure to talc who had no evidence of other mineral related disease.

\section{Case report}

A 65 year old woman was admitted to hospital with a nonproductive cough and progressive dyspnoea of two months' duration. She had no other medical problems, took no medication, had never smoked, and had no prior history of lung disease. She had worked for 25 years in a closed, poorly ventilated space lubricating rubber sheets with talc, and had retired eight years before admission.

She was mildly dyspnoeic at rest with a respiratory rate of 22 breaths a minute. Physical examination otherwise showed nothing abnormal except for fine bilateral basal end inspiratory crackles. The blood count and differential white cell count were normal, as were serum electrolyte concentrations, results of liver function tests, erythrocyte sedimentation rate, serum angiotensin converting enzyme activity, and rheumatoid factor and antinuclear antibody titres. Pulmonary function tests gave normal results with the exception of

Address for reprint requests: Dr David B Ettensohn, Division of Pulmonary Medicine, Memorial Hospital of Rhode Island, Pawtucket, Rhode Island, 02860 USA. mildly decreased single breath carbon monoxide transfer factor ( $71 \%$ of predicted). Steady state diffusion capacity did not increase with exercise. Resting arterial blood gas analysis showed: $\mathrm{pH} 7 \cdot 42$, carbon dioxide tension $\left(\mathrm{PCO}_{2}\right) 4.3 \mathrm{kPa}$, oxygen tension $\left(\mathrm{Po}_{2}\right) 8.3 \mathrm{kPa}$, and oxygen saturation $92 \%$. Posterior anterior and lateral chest radiographs were normal.

Bronchoalveolar lavage was performed as previously described $^{3}$ with three $40 \mathrm{ml}$ aliquots of saline in a lingular and right middle lobe subsegment. Analysis of the bronchoalveolar lavage specimens from the right and left lungs gave nearly identical results, as follows: percentage returned $68 \%$; cell number $22 \times 10^{6}$; alveolar macrophages $33.6 \%$; lymphocytes $63.6 \%$; polymorphonuclear leucocytes $2.2 \%$, and eosinophils $0.6 \%$. Normal values (mean (SD)) for analysis of lavage fluid from our laboratory (based on bronchoalveolar lavage performed on 74 normal non-smoking subjects) is as follows: percentage returned 63.4 (10.8); cell number 7.2 (3.9) $\times 10^{6}$; \% alveolar macrophages 95.0 (2.9); \% lymphocytes $4.0(2 \cdot 4)$; $\%$ polymorphonuclear leucocytes $0.84(1 \cdot 1)$, and $\%$ eosinophils $0.81(0.35)$. An open lung biopsy showed numerous peribronchiolar granulomas with foreign body giant cells and birefringent needle shaped particles within these cells (figure). $X$ ray probe microanalysis (performed by Dr J D Shelburne, department of pathology, Duke University Medical Center, Durham, North Carolina) showed that this birefringent material was talc (magnesium silicate). No asbestos or other silicates were identified in the tissue or by $x$ ray probe microanalysis.

The patient was treated with oral prednisone $1 \mathrm{mg} / \mathrm{kg}$ a day with rapid and dramatic improvement in dyspnoea and cough, and normalisation of diffusion capacity and hypoxaemia. The prednisone was tapered and discontinued over three months. One month following discontinuation of the steroids she presented with nearly identical symptoms and laboratory findings. Bronchoalveolar lavage was again performed (right middle lobe), with the following results: percentage returned $55 \%$, cell number $11 \times 10^{6}$; alveolar macrophages $51.2 \%$, lymphocytes $35.8 \%$; polymorphonuclear leucocytes $12 \cdot 8 \%$; eosinophils $0.2 \%$. T cell subset analysis of this specimen was performed with an immunoperoxidase stain $^{4}$ and monoclonal antibodies OKT4 (helperinducer cells) and OK T8 (suppressor-cytotoxic cells) (Ortho, Raritan, New Jersey) and showed a predominance of $\mathrm{T}^{+}$ cells $\left(65.6 \%\right.$ of total lymphocytes) relative to $\mathrm{T} 4^{+}$cells (19.2\% of total lymphocytes) and a decreased T4/T8 ratio of 0.29 (normal $>1.0$ ). Corticosteroid treatment was restarted with good results, and the patient has remained symptom free taking $15 \mathrm{mg}$ of prednisone every other day. 


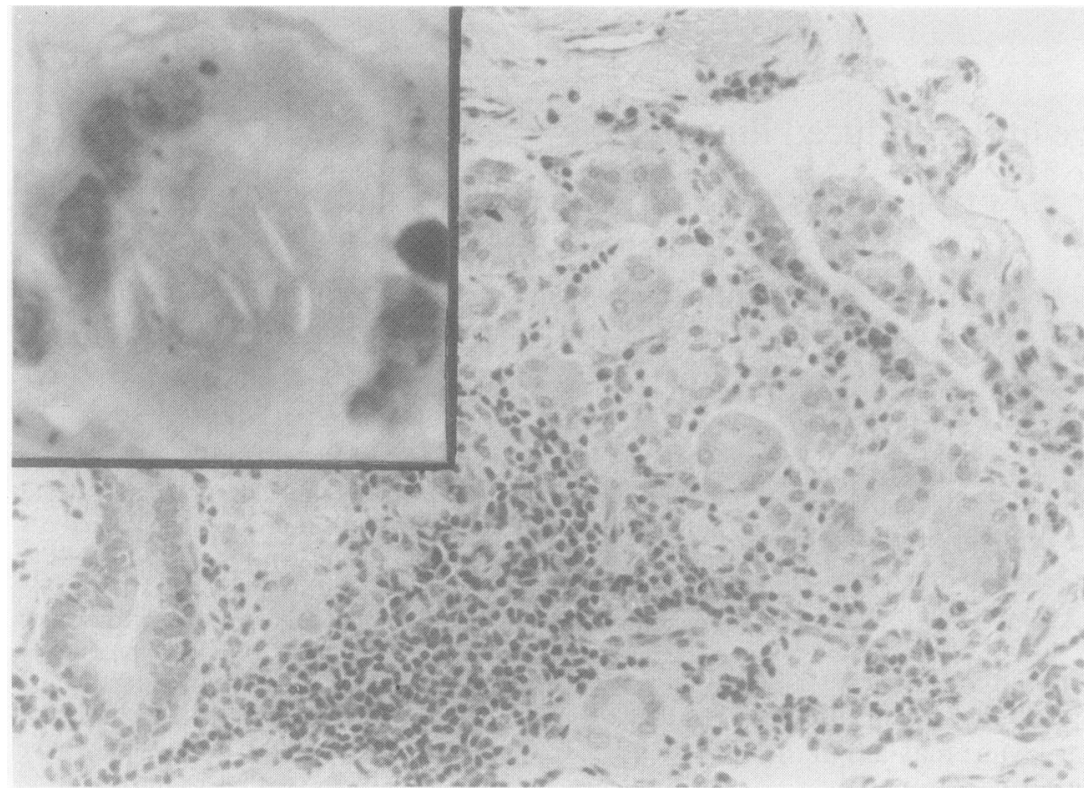

Photomicrograph of open lung biopsy specimen (haematoxylin $\vec{\circ}$ and eosin) showing peribronchiolar granuloma composed of foreign body giant cells surrounded by lymphocyte and (inset) needle shaped talc it crystals within the cytoplasm of a giant cell.

\section{Discussion}

It has been known since $1896^{5}$ that talc inhalation could lead to nodular, interstitial, and fibrotic pulmonary disease. ${ }^{16} \mathrm{As}$, however, talc may be heavily contaminated with asbestos or quartz or other silicates (or all of these), ' it has been difficult to distinguish talc related disease from that caused by these other minerals. The patient we describe provided a unique opportunity to explore the pathogenesis of talc lung as she had no other occupational exposures and there was no evidence of asbestos or other silicates that may have contributed to pathological changes.

The first bronchoalveolar lavage specimen showed an impressive lymphocytosis from both sides of the lung, but no $T$ cell subset analysis was performed. When this analysis was performed on the specimen obtained from the second bronchoalveolar lavage specimen there was a considerable predominance of $\mathrm{T}^{+}$lymphocytes. Although prior treatment with prednisone may have altered $\mathrm{T}$ cell subset ratios, the patient had not taken prednisone for one month before the analysis. In hypersensitivity pneumonitis, which is also characterised by a predominance of $\mathrm{T}^{+}$lymphocytes and clinical improvement associated with withdrawal from the offending antigen, treatment with prednisone had led to normalisation of $\mathrm{T}$ cell subset ratios. ${ }^{78} \mathrm{We}$ cannot entirely exclude the possibility that the abnormal $\mathrm{T}$ cell subset ratio we observed was related to the prednisone treatment, but prednisone is more likely to have attenuated the alteration.

This appears to be the first report of bronchoalveolar lavage findings in inhalation talcosis. Farber and coworkers reported sarcoid like chest radiographs in patients with pulmonary disease from intravenous talc injection and lymphocytosis (no subset analysis) in bronchoalveolar fluid. 9 The predominance of $\mathrm{T}^{+}$cells in the bronchoalveolar lavage fluid from this patient contrasts with the predominance of $\mathrm{T}^{+}$cells in other granulomatous diseases such as sarcoidosis and berylliosis, or in pure asbestosis. ${ }^{10}$ If these bronchoalveolar lavage findings are typical of the findings in talc lung, the pathogenesis of talc related pulmonary disease may similar to that of hypersensitivity pneumonitis and mix dust disease. $^{10}$

Our patient did not report respiratory symptoms during her 25 years of exposure to talc. Her first symptoms began $\frac{2}{(D}$ eight years after she retired. Possibly talc incites a foreign $\Omega$ body reaction that may require years to develop the mass of $\overrightarrow{\vec{O}}$ immune cells and mediators necessary to produce clinical 3 disease. As the talc cannot be removed and will presumably continue to incite the immune and inflammatory reaction which initially led to clinical disease, long term, perhaps lifelong corticosteroid treatment may be required. This is 0 supported by our patient's deterioration after withdrawal of corticosteroids. Bronchoalveolar lavage may be a useful tool to differentiate talc related disease from other granulomatous disorders and provide further insight into its pathogenesis.

This work was supported in part by grant HL-34116 from the National Heart, Lung, and Blood Institute.

\section{References}

1 Morgan WK, Seaton A (eds). Occupational lung disease. Philadelphia: Saunders 1984:296-300.

2 Kleinfeld M, Messite J, Kooyman O, Shapiro J. Pulmonary Ventilatory Function in Talcosis of the Lung. Dis Chest 1964;46:592-8.

3 Ettensohn DB, Roberts NJ Jr. Human alveolar macrophage support of lymphocyte responses to mitogens and antigens: analysis and comparison with autologous peripheral bloodderived monocytes and macrophages. Am Rev Respir Dis 1983;128:516-22.

4 Paradis IL, Merrall EJ, Krell JM, Dauber JH, Rogers RS, Rabin 
BS. Lymphocyte enumeration a comparison between a modified avidin-biotin immunoperoxidase system and flow cytometry. J Histochem Cytochem 1984;32:358-62.

5 Thorel $C$. Talc lung. A contribution to the pathological anatomy of pneumoconiosis. Beit Pathol Anat Algem Pathol 1896;20: 85-101.

6 Kleinfeld M, Messite J, Shapiro J, Swenciki R. Effect of talc dust inhalation on lung function. AMA Arch Environ Health 1965;10:431-7.

7 Costabel U, Bross KJ, Marxen J, Matthys H. T Lymphocytosis in bronchoalveolar lavage fluid of hypersensitivity pneumonitis: changes in profile of $\mathrm{T}$ cell subsets during the course of disease. Chest 1983;85:514-8.

8 Farber HW, Fairman RP, Glauser FL. Talc granulomatosis: laboratory findings similar to sarcoidosis. Am Rev Respir Dis 1982;125:258-61.

9 Akoun G, Herman DP, Milleron BS, Mayaud CM, Perrot JY Bronchoalveolar T-cell subsets in gold lung: Evidence for a hypersensitivity reaction [letter]. Chest 87:135-6.

10 Costabel U, Bross KJ, Huck E, Guzman J, Matthys H. Lung and blood lymphocyte subsets in asbestosis and in mixed dust pneumoconiosis. Chest 1987;91:110-2. 